\title{
Biomass and carbon stocks in mangrove ecosystems of Kerala, southwest coast of India
}

\author{
K. M. Harishma1*, S. Sandeep ${ }^{2}$ and V. B. Sreekumar ${ }^{1}$
}

\begin{abstract}
Background: Mangroves are important tropical carbon sinks, and their role in mitigating climate change is well documented across the globe. However, the ecosystem carbon stocks in the mangroves of India have not been studied comprehensively. Data from this region is very limited for providing sufficient insights and authentic evaluation of carbon stocks on a regional scale. In this study, we evaluated the ecosystem carbon stock and its spatial variation in mangroves of Kerala, southwest coast of India.

Results: The mean biomass stored in mangrove vegetation of Kerala is $117.11 \pm 1.02 \mathrm{t} / \mathrm{ha}$ ( $\mathrm{ABG}=80.22 \pm 0.80, \mathrm{BGB}=$ $36.89 \pm 0.23 \mathrm{t} / \mathrm{ha}$ ). Six mangrove species were found distributed in the study area. Among the different species, Avicennia marina had the highest biomass (162.18 t/ha) and least biomass was observed in Sonneratia alba (0.61 t/ha). The mean ecosystem carbon stock of mangrove systems in Kerala was estimated to be 139.82 t/ha, equivalent to 513.13 t CO 2 e/ha with the vegetation and soil storing $58.56 \mathrm{t} \mathrm{C/ha}$ and $81.26 \mathrm{t} \mathrm{C} /$ ha respectively.

Conclusion: The present study reveals that Kerala mangroves store sizable volume of carbon and therefore need to be preserved and managed sustainably, to retain along with the increase in carbon storage. This features the need of broadening mangrove cover as well as restoring deteriorated land in the past 50 years. Although mangrove forests in this region are protected by the Kerala Forest Department, they have been frequently facing illegal encroachment, prawn cultivation, and coastal erosion.
\end{abstract}

Keywords: Mangrove ecosystem, Biomass, Aboveground carbon, Belowground carbon, Ecosystem carbon stock

\section{Background}

The 1997 Kyoto Protocol was framed on the principle that $\mathrm{CO}_{2}$ from the air can be sequestered in the soil and biomass, a practical way of mitigating climate change. Blue carbon sinks, which encompass vegetated coastal habitats like seagrass meadows, salt marshes, and mangrove forests, rank among the most profound carbon sinks in the biosphere. Recently, these submerged ecosystems have gained much attention as these are among the most carbon-rich forests in the tropic (Duarte et al. 2005; Nellemann et al. 2009a, 2009b).

Mangroves are considered as potential sinks of atmospheric carbon having a significant role in the global

\footnotetext{
* Correspondence: harishmakm.km@gmail.com

'Department of Forest Botany, Kerala Forest Research Institute, Peechi, Kerala 680653 , India

Full list of author information is available at the end of the article
}

carbon cycle (Matsui et al. 2010). Mangrove plants are highly productive (Alongi 2014), and it is estimated that the average annual carbon sequestration rate of mangrove ecosystems averages between 6 and $8 \mathrm{Mg} \mathrm{CO}_{2}$ e/ ha (tons of $\mathrm{CO}_{2}$ equivalent per hectare) (Murray et al. 2011). These rates are approximately 2 to 4 times higher than global rates observed in mature tropical forests and are considered as one of the largest and productive pools of carbon (Nellemann et al. 2009a, 2009b). However, estimations from regional mangrove carbon sinks are limited due the geographical disparity in their carbon stocks (Kauffman et al. 2011). Currently, management of these carbon sinks are excluded from the international schemes for carbon payment and national carbon inventories and as such are not included in climate change policies. 
Mangrove cover of India is estimated as $4639 \mathrm{~km}^{2}$, occupying $3 \%$ of the global mangroves (FAO 2007; Forest Survey of India 2009). The inventory of carbon stocks in mangrove ecosystems are scanty, and currently only a few studies have reported the ecosystem carbon stocks of these systems in India (Pandey and Pandey 2013; Sahu et al. 2016; Suresh et al. 2017). Kerala lies in the southwestern tip of peninsular India with a shoreline of $590 \mathrm{~km}$ and rich mangrove patches. The mangrove areas in Kerala have been dwindling widely in the past few decades from $\sim 7000$ ha in 1985 to 1095 ha in 1994 and 2502 ha in 2014 (Basha 1991; Kurian 1994; Ramachandran et al. 1985; Vidyasagaran and Madhusoodanan 2014). Even though there were various attempts to estimate the mangrove cover of Kerala, the actual figure is still elusive and such limitations in data restrain insights and authentic evaluation of carbon stocks on a regional scale. The present study evaluated the ecosystem carbon stock and its spatial variation in the mangrove ecosystems of Kerala, India.

\section{Materials and methods Study area}

The Kerala state is located in the southwest corner of India between $10^{\circ} 51^{\prime} 1.8576^{\prime \prime} \mathrm{N}$ and $76^{\circ} 16^{\prime} 15.8880^{\prime \prime} \mathrm{E}$ with a total area of $38,863 \mathrm{~km}^{2}$. The region has a long coastal belt of $590 \mathrm{~km}$ with rich mangrove ecosystems as narrow strips along the coast. The study was conducted from April 2017 to March 2018. The area experiences a humid climate with annual average rainfall of $2664.9 \mathrm{~mm}$. Recent estimations by the Indian Space Research Organization (ISRO) show the mangrove cover of Kerala state as $6.63 \mathrm{~km}^{2}$ (SAC 2012). A stratified random sampling was used wherein the entire region was classified into three zones: northern zone $\left(75.280091^{\circ}\right.$ to $75.284046^{\circ} \mathrm{E}$ and $12.020338^{\circ}$ to $12.018587^{\circ}$ $\mathrm{N})$, central zone $\left(76.062087^{\circ}\right.$ to $76.064901^{\circ} \mathrm{E}$ and $10.547201^{\circ}$ to $\left.10.546128^{\circ} \mathrm{N}\right)$, and southern zone $\left(76.550405^{\circ}\right.$ to $76.560820^{\circ} \mathrm{E}$ and $8.937838^{\circ}$ to $\left.8.934120^{\circ} \mathrm{N}\right)$. These zones served as the main strata, and within each zone, substrata were established based on the canopy density classification scheme proposed by the Forest Survey of India (FSI 2013). Three levels of canopy density were considered for sampling using a spherical crown densitometer: (i) canopy density of above 70\% (very dense), (ii) canopy density between 40 and 70\% (moderately dense), and (iii) canopy density between 10 and 40\% (open).

A total of 30 sampling plots (10 plots in each zone) of size of $10 \mathrm{~m} \times 10 \mathrm{~m}$ was established for non-destructive determination of biomass and soil carbon stock as well as species composition. The total sampling area covered was 3 ha. According to Sujanapal et al. (2014), there are 18 mangrove species recorded from Kerala. The number of plots in each zone was fixed by plotting species-area curve and selecting the plots by random integer generator function in Microsoft Excel. To mark the exact location of each sampling site, a global positioning system, GPS (Garmin Etrex 10), was used and the spatial location of each quadrant was recorded (Fig. 1).

\section{Aboveground and belowground biomass carbon stocks}

All mangrove trees $\geq 10 \mathrm{~cm}$ in girth was measured at breast height $(\mathrm{GBH}, 1.37 \mathrm{~m})$ to the nearest centimeter and identified to the species level. The diameter of the trees were calculated by dividing the girth by $\pi$ (Brock et al. 2006). Allometric equations developed by Komiyama et al. (2005) for mangrove species in Southeast Asia were used for the estimation of aboveground biomass $\left(W_{\text {top }}\right)$ and belowground biomass $\left(W_{\mathrm{R}}\right)$ as

$$
\begin{aligned}
& W_{\text {top }}=0.251 \rho \mathrm{D}^{2.46} \\
& W_{\mathrm{R}}=0.199 \rho^{0.899} \mathrm{D}^{2.22}
\end{aligned}
$$

where $\rho$ is the wood density of the respective species. The wood density of different mangrove species was obtained from the World Agroforestry Database (Chave et al. 2009). The values of aboveground biomass and belowground biomass were summed to get the total biomass for all the plots, and this biomass value was averaged to get mean total biomass (tons/hectare). The carbon content was calculated by multiplying the individual tree biomass with the conversion factor 0.5 (IPCC 2006). Since understory vegetation (seedlings and herbs) is negligible in mangrove systems, they were not considered for ecosystem carbon stock estimations (Kauffman and Donato 2012; Vinod et al. 2018).

\section{Soil sample collection}

A PVC core having $60 \mathrm{~cm}$ length and $2 \mathrm{~cm}$ radius was used for the collection of soil samples from selected plots. The soil samples from were collected from two depths (0$30 \mathrm{~cm}$ and $30-60 \mathrm{~cm}$ ) using the PVC core and stored in clean polythene bags. Bulk density was estimated from the core samples by dividing the dry weight (oven-dried at a temperature of $105{ }^{\circ} \mathrm{C}$ to a constant weight) of the soil sample by the volume of core. Simultaneously, bulk soil samples were also collected from each plot using (0-30 $\mathrm{cm}$ and $30-60 \mathrm{~cm}$ ) a Eijkelkamp Dutch auger (Aryal et al. 2018; de Blécourt et al. 2013; Motsara and Roy 2008; Sheikh et al. 2009) for the estimation of organic carbon. It was air dried, powdered, and sieved ( $2 \mathrm{~mm}$ sieve) for further analysis. Three replications of the samples were collected in all cases. Care was taken to select only natural mangrove systems, and planted systems were avoided to minimize the bias that would have happened during selection of the species in planted mangrove systems. 


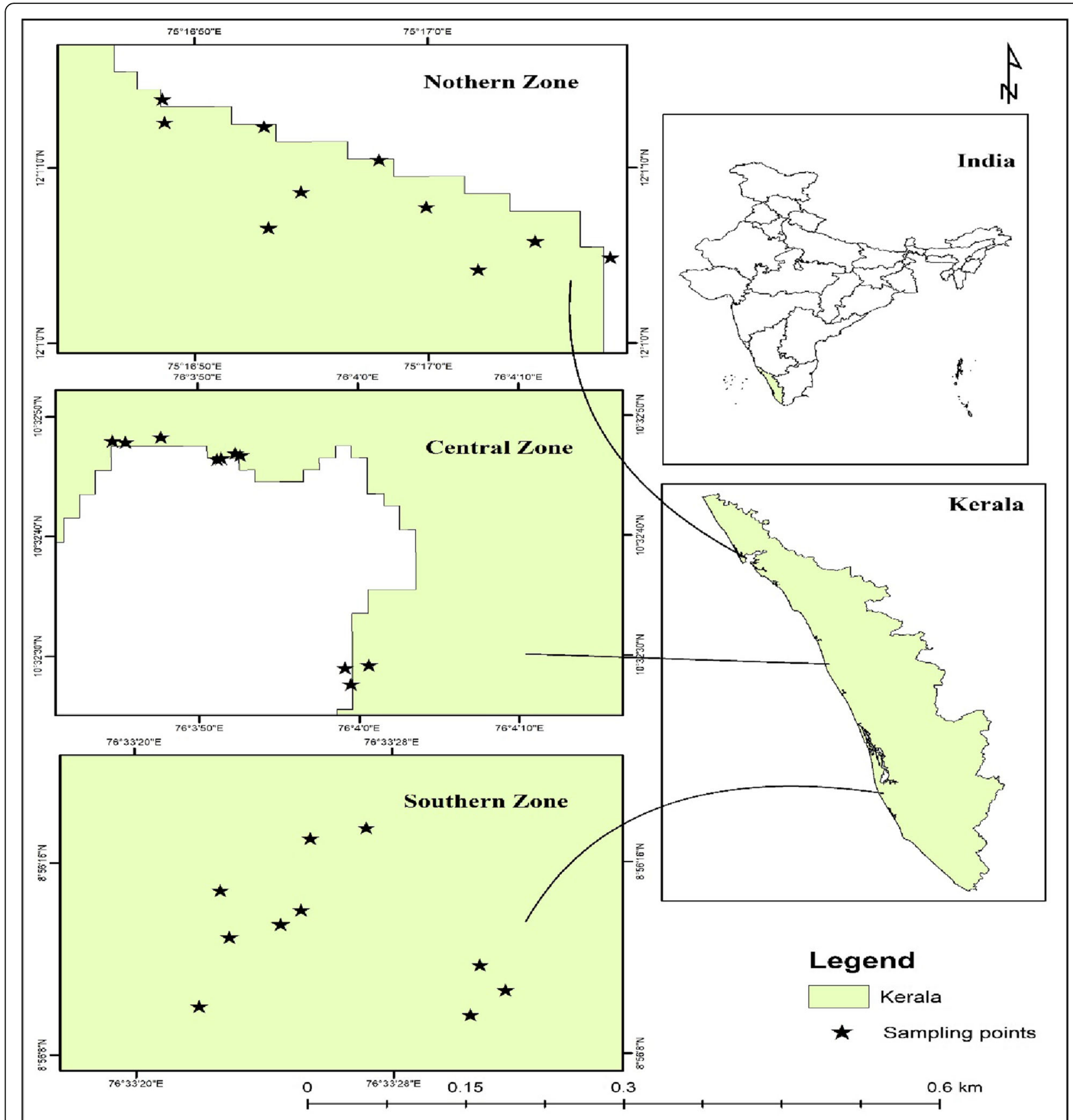

Fig. 1 Study area showing sampling points of mangrove

\section{Soil analysis}

Organic carbon in the samples were determined by sulfuric acid and potassium dichromate wet digestion method using ferroin as indicator (Walkley and Black 1934).

\section{Soil carbon stocks}

Soil carbon stocks (SCS) in each layer was determined as:

$$
\mathrm{SCS}\left(\mathrm{kg} \mathrm{C} / \mathrm{m}^{2}\right)=\mathrm{C} \times \mathrm{T} \times \mathrm{BD}
$$

where $C$ is organic carbon concentration (\%), $T$ is the layer thickness $(\mathrm{m})$, and BD is the bulk density $\left(\mathrm{kg} \mathrm{m}^{-3}\right)$.

The total carbon stock was estimated as:

Total carbon stock ( $\mathrm{t} / \mathrm{ha})=C_{\text {treeAGB }}+C_{\text {treeBGB }}+C_{\text {soil }}$

This total carbon stock was converted into $\mathrm{CO}_{2}$ equivalents by multiplying with the factor 3.67. The factor was derived as the ratio of molecular weight between 
carbon and carbon dioxide (Kauffman and Donato 2012).

\section{Results and discussion Floristic composition}

A total of 6 species, i.e., Avicennia officinalis, Rhizophora mucronata, Avicennia marina, Bruguiera cylindrica, Rhizophora apiculata, and Sonneratia alba, from 3 families and 4 genera were recorded from the selected zones. A total of 628 individuals over $10 \mathrm{~cm} \mathrm{GBH}$ were enumerated from the $30(10 \times 10 \mathrm{~m})$ plots in 3 zones. Among them, $36.62 \%$ were found to be of a single species, $A$. marina. R. mucronata, A. officinalis, and B. cylindrica were the other major species occupying $28.66 \%, 17.65 \%$, and $15.76 \%$ respectively of the total species recorded from the region. The remaining $1.27 \%$ was collectively represented by $R$. apiculata and S. alba (Fig. 2). A study by Sujanapal et al. (2014) has reported 18 true mangrove species from Kerala. But the distribution of most of the species was limited to certain estuarine pockets indicating very less diversity for most of the species in the region. Usually, an increase in the number of the plant species is an index of ecosystem health in wetlands. But in the case of mangroves, their species distribution is restricted by competition, salinity, and other physical factors (Hogarth 2007).

\section{Vegetation characteristics}

Tree height and GBH in the 3 zones showed a significant variation among them with the values ranging from 1.35 to $16.5 \mathrm{~m}$ height with a mean height of $5.06 \pm 0.11$ $\mathrm{m}$ and $\mathrm{GBH}$ of $10 \mathrm{~cm}$ to $228 \mathrm{~cm}$ with a mean girth of $21.24 \pm 0.70 \mathrm{~cm}$. The maximum height (2.3 to $16.5 \mathrm{~m})$ was observed in the mangrove systems of northern zone of Kerala and lowest in the southern zone (1.69 to 7.9 $\mathrm{m})$. In central Kerala, the height of the mangrove trees was found to be similar to northern mangrove patches (1.35 to $15 \mathrm{~m})$. Considering overall zone-wise mean height, the highest average height with $7.72 \pm 1.6 \mathrm{~m}$ was recorded in northern patches followed by central and southern Kerala with an average height of $3.35 \pm 0.11 \mathrm{~m}$ to $3.49 \pm 0.06 \mathrm{~m}$ respectively (Table 1 ).

Among the 6 mangrove species generally found along the Kerala coast, $R$. mucronata was found to have the maximum GBH (girth at breast height) (25.74 \pm 1.03 $\mathrm{cm})$ and height $(8.28 \pm 0.18 \mathrm{~m})$. Lowest height and $\mathrm{GBH}$ was recorded in $A$. officinalis $(3.36 \pm 0.22 \mathrm{~m})$ and $B$. cylindrica $(17.90 \pm 1.10 \mathrm{~cm})$ respectively (Table 2$)$. Based on the overall GBH, height, and plant density from each zone, it could be concluded that the mangrove stands of northern Kerala seem to be older than central and southern patches (Table 1).

\section{Biomass}

The mean biomass of mangroves in Kerala was found to be $117.12 \pm 1.02 \mathrm{t} / \mathrm{ha}$ (Table 4), and there were considerable variations in the biomass between different species (range 13.89-548 t/ha; SD = 121.24 t/ha). Comparing the biomass of the mangrove species in different regions of Kerala, the northern zone was found to have the maximum biomass with $246.56 \mathrm{t} / \mathrm{ha}$ with a recruit density of 2380 trees/ha. The lowest biomass was observed in central Kerala $(48.55 \mathrm{t} / \mathrm{ha})$ with a recruit density of 1690 trees/ha. The southern zone had a mean biomass of $56.25 \mathrm{t} /$ ha with a recruit density of 2210 trees/ha. Earlier studies by Vinod et al. (2018) have reported $236.56 \mathrm{t} / \mathrm{ha}$ of biomass from Kadalundi mangroves (Northern Kerala) and $132.83 \pm 97.5 \mathrm{t} \mathrm{C} /$ ha from the central zone (Suresh et al. 2017). Such mismatches in the biomass values indicated a very high variability across different patches in different zones.

The average aboveground biomass of the study area was estimated to be $80.23 \pm 15.95 \mathrm{t} / \mathrm{ha}$, and the average belowground biomass was $36.90 \pm 6.23 \mathrm{t} / \mathrm{ha}$. The results are similar to the reported aboveground biomass values from East Sumatra and Sri Lanka (Amarasinghe and

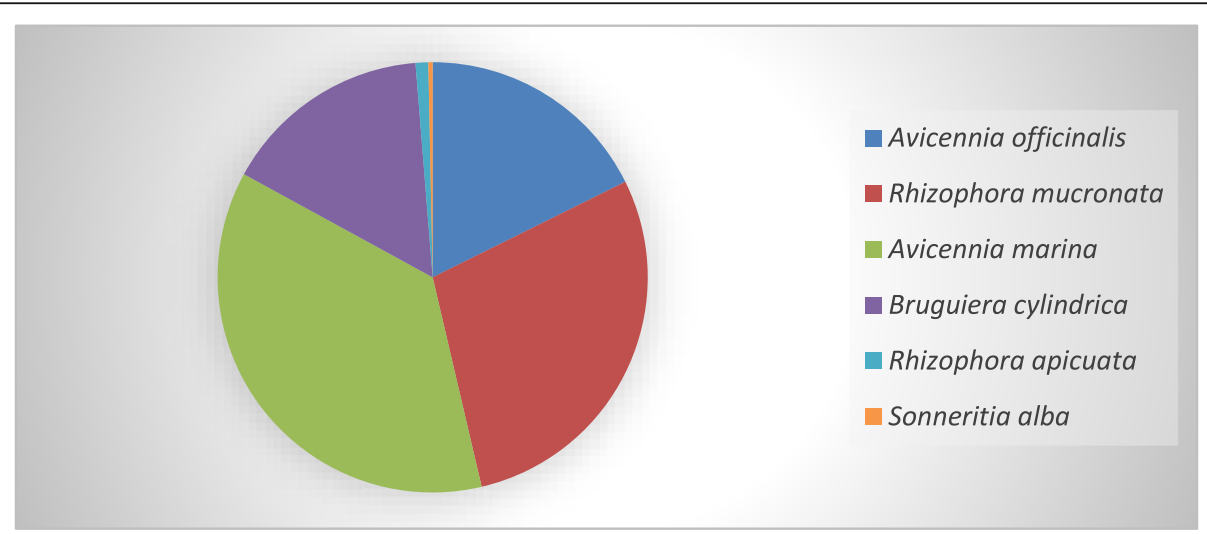

Fig. 2 Mangrove species density in the study area 
Table 1 Zone-wise height and GBH

\begin{tabular}{llll}
\hline Zone & Height $(\mathrm{m})$ & $\mathrm{GBH}(\mathrm{cm})$ & Tree density (per ha) \\
\hline Northern zone & $7.72 \pm 0.17$ & $30.34 \pm 1.66$ & 2380 \\
Central zone & $3.35 \pm 0.11$ & $15.74 \pm 0.40$ & 1690 \\
Southern zone & $3.49 \pm 0.06$ & $15.61 \pm 0.28$ & 2210 \\
\hline
\end{tabular}

Balasubramaniam 1992; Kusmana et al. 1992). The range of overall aboveground biomass in the study plots (8.87397.03 t/ha) was commensurate with what has been reported from Guadeloupe, Puerto Rico, Japan, Australia, Senegal, Thailand, Florida, and Sundarbans estuarine delta along the Bay of Bengal but lower than the studies conducted in Indonesia, Malaysia, Sri Lanka, Andaman Islands, and the Philippines.

The average biomass values reported from the mangroves in Kerala was greater than the values from the tropical dry forests of Kerala (Padmakumar et al. 2018). Komiyama et al. (2008) indicated that the biomass gradient in different mangrove zones will be influenced by the distance from the sea to the mangrove systems. Accordingly, the aboveground biomass values tend to be relatively low in the mangrove systems near the sea. In the present study, the northern zone mangroves are placed relatively farther from the sea when compared with the other two zones.

Among the different species, the highest biomass of $108.23 \mathrm{t} / \mathrm{ha}$ was recorded in Avicennia marina (above ground biomass $=82.22 \pm 1.55 \mathrm{t} / \mathrm{ha}$, root biomass $=25.99$ $\pm 0.037 \mathrm{t} / \mathrm{ha}$ ) located in the northern zone of Kerala and lowest biomass in Sonneratia alba having $0.61 \mathrm{t} /$ ha in the southern zone. In northern region, biomass of other species such as Avicennia officinalis, Bruguiera cylindrica and Rhizophora mucronata were, 33.62 t/ha, 21.22 t/ha, 83.48 $\mathrm{t}$ / ha biomass respectively.

In the southern region, Avicennia marina was found to have $53.96 \mathrm{t} / \mathrm{ha}$ and was the highest reported biomass from the southern plots for a single species. In the central region, the maximum recorded biomass was $15.27 \mathrm{t} /$ ha for Avicennia officinalis, and the minimum biomass was recorded from the southern region and central region in Sonneratia alba and Bruguiera cylindrica (0.04 t/ ha and $9.72 \mathrm{t} /$ ha respectively). The biomass recorded was specific for each species, which may be due to adaptabilities of these species to environmental variables. The accumulation of biomass is primarily influenced by species, age of tree, climate, management regime, proximity to water channel, and nutrient sediment that
Table 3 Soil organic carbon stock in each zone

\begin{tabular}{llllll}
\hline Zone & OC & BD & Depth & $\mathrm{kg} \mathrm{C} / \mathrm{ha}$ & Average kg C/ha \\
\hline Central 1 & $2.43 \pm 0.28$ & 0.91 & $0-30$ & 124.99 & $100.80 \pm 14.81$ \\
& $1.48 \pm 0.31$ & 1.32 & $30-60$ & & \\
Central 2 & $2.55 \pm 0.42$ & 0.90 & $0-30$ & 103.51 & \\
& $1.25 \pm 0.10$ & 0.93 & $30-60$ & & \\
Central 3 & $1.70 \pm 0.12$ & 0.79 & $0-30$ & 73.90 & \\
& $1.34 \pm 0.13$ & 0.84 & $30-60$ & & \\
Northern 1 & $1.66 \pm 0.35$ & 1.17 & $0-30$ & 104.02 & $90.96 \pm 7.11$ \\
& $1.31 \pm 0.29$ & 1.17 & $30-60$ & & \\
Northern 2 & $1.54 \pm 0.24$ & 1.08 & $0-30$ & 89.31 & \\
& $1.10 \pm 0.24$ & 1.20 & $30-60$ & & \\
Northern 3 & $1.75 \pm 0.21$ & 0.88 & $0-30$ & 79.54 & \\
& $1.20 \pm 0.16$ & 0.93 & $30-60$ & & \\
Southern 1 & $1.24 \pm 0.17$ & 1.04 & $0-30$ & 66.26 & $52.04 \pm 8.55$ \\
& $0.77 \pm 0.13$ & 1.21 & $30-60$ & & \\
Southern 2 & $0.73 \pm 0.16$ & 0.95 & $0-30$ & 53.13 & \\
& $0.94 \pm 0.30$ & 1.16 & $30-60$ & & \\
Southern 3 & $0.88 \pm 0.15$ & 0.83 & $0-30$ & 36.71 & \\
& $0.44 \pm 0.04$ & 1.13 & $30-60$ & & \\
\hline
\end{tabular}

supplement mangrove productivity (Kairo et al. 2008; Fatoyinbo et al. 2008).

The aboveground biomass (AGB) and belowground biomass (BGB) contributed $68.49 \%$ and $31.51 \%$, respectively, to the total mangrove biomass, and this is almost equal to the mangrove systems in the oligohaline zones of Sundarbans, Bangladesh (Kamruzzaman 2017). The ratio of $\mathrm{AGB}$ to $\mathrm{BGB}$ was found to range from 1.5 to 2.6 with an average of 2.17 and was comparable with that of the mangroves in Mahanadi Delta, India, having an average of 2.3 (Sahu et al. 2016), and studies conducted in global scale (Komiyama et al. 2008). However, the biomass estimation from upland forests from different parts of the world has shown that the AGB to BGB ratio of mangrove forests was relatively lower than upland forests. The lower AGB to BGB ratio for mangroves indicates a large amount of biomass allocation in the belowground root system that can be considered a requisite adaptation for mangroves to stand firmly in muddy conditions.

\section{Vegetation carbon stock}

The average vegetation carbon stock of Kerala mangroves was found to be $58.56 \pm 0.51 \mathrm{t} \mathrm{C} /$ ha (Table 4).

Table 2 Species-wise height and GBH

\begin{tabular}{|c|c|c|c|c|c|c|}
\hline & Avicennia marina & Avicennia officinalis & Bruguiera cylindrica & Rhizophora apiculata & Rhizophora mucronata & Sonneratia alba \\
\hline $\mathrm{GBH}(\mathrm{cm})$ & $20.28 \pm 1.46$ & $19.35 \pm 1.65$ & $17.90 \pm 1.10$ & $16.52 \pm 1.72$ & $25.74 \pm 1.03$ & $19.68 \pm 5.63$ \\
\hline Height (m) & $3.81 \pm 0.11$ & $3.36 \pm 0.22$ & $4.09 \pm 0.13$ & $4.04 \pm 0.49$ & $8.28 \pm 0.18$ & $5.05 \pm 2.05$ \\
\hline
\end{tabular}


Species contribution of the different mangrove species to the average carbon stock was in the order of $A$. marina $>R$. mucronata $>$ A. officinalis $>B$. cylindrica $>R$. apiculata $>$ S. alba (Fig. 3).

The biomass carbon stock of the northern region of Kerala was estimated to be $123.28 \pm 1.36 \mathrm{t}$ C/ha and was found to be the most carbon-rich mangrove region indicating a positive correlation between tree density and biomass and carbon storage. According to Syamani and Susilawati (2012), the increase in biomass was mainly due to the photosynthetic activities resulting in horizontal and vertical growth. Chanan (2012) stated that each expansion of biomass substance will be trailed by increment in carbon stock.

In the southern region, the total carbon stock estimated was $28.13 \pm 0.10 \mathrm{C} / \mathrm{ha}$, and species such as $A$. marina, $R$. apiculata, and S. alba contributed $26.98 \mathrm{t} \mathrm{C/ha,} 0.85 \mathrm{t} \mathrm{C/}$ ha, and $0.31 \mathrm{t} \mathrm{C/ha}$ respectively to the total estimated stocks. The central zone was the least carbon-rich area with a total carbon stock of $24.28 \pm 0.08 \mathrm{t} \mathrm{C} / \mathrm{ha}$. The contribution of species to the carbon stock in this region was in the order of $A$. officinalis $>B$. cylindrica $>R$. mucronata. The difference in the carbon stocks in the vegetation biomass of mangrove systems in different zones may be attributed to the structural peculiarities of the stands in each region (Kasawani et al. 2007).

\section{Soil carbon stock}

The general trend in soil bulk density and organic carbon in different mangrove zones is summarized in Table 3. The bulk density and organic carbon storage in the mangrove systems were found to be inversely correlated. The soil carbon content in the top $30 \mathrm{~cm}$ was comparatively higher than the lower layers. Soil organic carbon stored in the upper 60 $\mathrm{cm}$ depth of the mangrove sediment was estimated to be in the range of 36.71-124.99 $\mathrm{t} \mathrm{C} / \mathrm{h}$ a with an average soil carbon stock of $81.26 \pm 10.16 \mathrm{t} \mathrm{C} /$ ha. It was comparable with that of the studies in Bahamas, Saudi Arabia (Atwood et al. 2017) but lower than the values obtained by Micronesian mangroves (Kauffman et al. 2011) and higher than that of Mahanadi Mangrove Delta, India (Sahu et al. 2016). Among the different zones, the highest soil organic carbon (SOC) was recorded from the central zone $(100.80 \pm 14.81 \mathrm{t} \mathrm{C} / \mathrm{ha})$ of Kerala and lowest from southern zone $(52.04 \pm 8.55 \mathrm{t} \mathrm{C/}$ ha). Statistical analysis showed that the SOC of central and southern zone varied significantly $(F=5.82)$. Studies have showed that there can be significant variation in soil carbon stocks across different mangrove forests and sometimes with in the same mangrove forests (Adame et al. 2015; Jardine and Siikamäki 2014; Kauffman et al. 2011). The soil in the mangroves is considered as one of the major carbon pool (Donato et al., 2011, b; Kauffman et al. 2011), and it has been proven that sediment carbon stock accounts for $58 \%$ of total carbon stock in these systems.

It was observed that canopy cover had significant influence on soil carbon stocks. Accordingly, the central zone "1" (124.99 t C/ha), northern zone "1" (104.02 t $\mathrm{C} / \mathrm{ha})$, and southern zone "1" (66.26 t C/ha) had the highest soil carbon stock, and the lowest carbon stocks were found in the open category in each zone. The highest carbon stock recorded from the densely covered plots may be due to the higher litter production that was added to the soil as carbon input. The mangrove litter added to the soil could decompose and get incorporated in to the underlying mineral soil layer thereby affecting the soil carbon dynamics (Niu et al. 2019). The soil carbon in the upper layers contents are usually the most vulnerable owing to the direct interaction with atmosphere and erosional forces. The higher carbon contents in the mangrove systems compared to forest $(55.40 \mathrm{t} \mathrm{C} /$ ha), rubber ( $43.73 \mathrm{t} \mathrm{C/} \mathrm{ha),} \mathrm{home} \mathrm{gardens}(37.78 \mathrm{t} \mathrm{C/ha})$, coconut $(26.42 \mathrm{t} \mathrm{C/ha})$, and rice paddy $(17.74 \mathrm{t} \mathrm{C/ha})$ indicated the higher potential of mangrove soils to act as a

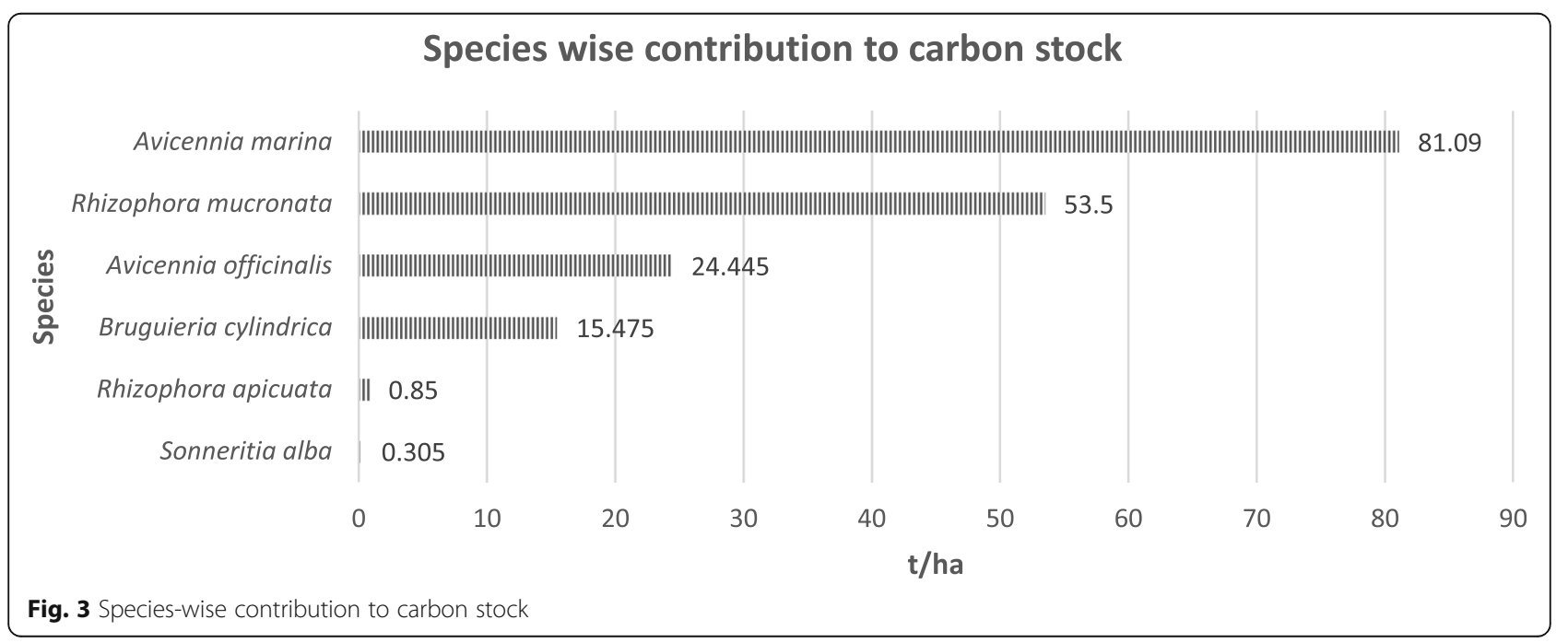


Table 4 Zone wise Biomass, Vegetation carbon stock, Soil carbon stock, Ecosystem carbon stock, $\mathrm{CO}_{2}$ equivalent

\begin{tabular}{|c|c|c|c|c|c|}
\hline Zone & Biomass (t/ha ) & Vegetation carbon stock (t C/ha) & Soil carbon stock (t C/ha) & Ecosystem carbon stock (t C/ha) & $\mathrm{CO}_{2}$ equivalent $\left(\mathrm{t} \mathrm{CO}_{2} / \mathrm{ha}\right)$ \\
\hline North & $246.56 \pm 2.71$ & $123.28 \pm 1.36$ & $90.96 \pm 7.11$ & $214.24 \pm 8.47$ & 786.25 \\
\hline Central & $48.55 \pm 0.16$ & $24.28 \pm 0.08$ & $100.80 \pm 14.81$ & $125.08 \pm 14.90$ & 459.03 \\
\hline South & $56.25 \pm 0.2$ & $28.13 \pm 0.10$ & $52.04 \pm 8.55$ & $80.16 \pm 8.65$ & 294.19 \\
\hline Average & $117.11 \pm 1.02$ & $58.56 \pm 0.51$ & $81.26 \pm 10.16$ & $139.82 \pm 10.67$ & 513.13 \\
\hline
\end{tabular}

better carbon reservoir than other common land uses in the region (Saha et al. 2010).

\section{Ecosystem carbon stock}

The mean ecosystem carbon stock of Kerala was estimated to be $139.82 \pm 10.67 \mathrm{t} \mathrm{C/ha} \mathrm{(Table} \mathrm{4).} \mathrm{However,}$ the ecosystem carbon values in the mangrove systems of Kerala was found to be much lesser than the 332-2205 t $\mathrm{C} / \mathrm{ha}$ reported for natural and replanted mangroves in Southeast Asia (Alongi 2012) and the global mean carbon stocks in mangroves ( $885 \mathrm{t} \mathrm{C/ha)} \mathrm{reported} \mathrm{by} \mathrm{Kauff-}$ man and Bhomia (2017). The mean carbon stock of northern, central, and southern zones of mangrove were $214.24 \pm 8.47 \mathrm{t} \mathrm{C} / \mathrm{ha}, 125.08 \pm 14.90 \mathrm{t} \mathrm{C} / \mathrm{ha}$, and $80.16 \pm$ $8.65 \mathrm{t} \mathrm{C} /$ ha respectively. The mean $\mathrm{C}$ stock in the northern region was higher than that of the other two zones which may be due to the higher tree density, GBH, and height of mangroves in this zone. The distribution of carbon stock in mangroves was $42 \%$ and $58 \%$ in the vegetation and soil respectively. Studies have shown that soil organic carbon is the largest component of total carbon stock, especially in areas that have lost their natural vegetation or not naturally forested (Scharlemann et al. 2014). There exists a possibility of underestimating the SOC in the present study as carbon contents were estimated only up to $60 \mathrm{~cm}$ due to water level restricting sampling depth whereas in reality, it would extend up to several meters (Fujimoto 2004; Kauffman et al. 2011). The average estimated $\mathrm{CO}_{2}$ equivalent of Kerala mangroves was $513.13 \mathrm{t} \mathrm{CO}_{2} /$ ha (Table 4). This value was interpreted as an indicative value rather than a prognosis and helps to highlight the importance of mangrove conservation and estimation of mangrove ecosystems in the world (Donato et al. 2011; Kauffman et al. 2014).

\section{Conclusion}

A comprehensive assessment of the $\mathrm{C}$ stocks in the mangrove systems of Kerala, southwestern tip of India, shows that this region has a capacity to sequester $139.82 \mathrm{t} \mathrm{C} / \mathrm{ha}$ within this specific ecosystem. Among the different mangrove zones of Kerala, the northern part of Kerala was found to store relatively more carbon because of its higher tree density, soil carbon content, and biometric peculiarities (tree height and GBH). The allocation of $\mathrm{C}$ stock in the mangrove ecosystems of the region was $42 \%$ in vegetation and $58 \%$ in the soil pools. The findings of the present study add to the present knowledge gap in the ecosystem functioning dimensions of a major mangrove system in India and contribute to reliable and informed decision-making in their management.

\section{Abbreviations \\ $\mathrm{CO}_{2}$ : Carbon dioxide; $\mathrm{W}_{\text {top }}$ : Aboveground biomass; $\mathrm{W}_{\mathrm{R}}$ : Belowground biomass; SCS: Soil carbon sock; BD: Bulk density; GBH: Girth at breast height; ABG: Aboveground biomass; BGB: Belowground biomass; SOC: Soil organic carbon}

\section{Acknowledgements}

The authors acknowledge the financial support provided by the Kerala Council for Science, Technology, and Environment (KSCSTE), India. The infrastructural facilities provided by the Forest Department, Govt. of Kerala, and Kerala Forest Research Institute, Peechi, are gratefully acknowledged.

\section{Authors' contributions}

Harishma K M designed and drafted the manuscript with the help of S Sandeep. V B Sreekumar contributed to the revision of the first draft. All authors have read and approved the final manuscript.

\section{Funding}

The Kerala Council for Science, Technology, and Environment (KSCSTE), India, provided the funding for this whole work including surveys and wages.

\section{Availability of data and materials}

The datasets generated and analyzed during the current study are not publicly available, because this data is from an unpublished Ph.D. work of the corresponding author, but are available from the corresponding author on reasonable request.

Ethics approval and consent to participate

Not applicable

\section{Competing interests}

The authors declare that they have no financial and nonfinancial competing interests.

\section{Author details}

${ }^{1}$ Department of Forest Botany, Kerala Forest Research Institute, Peechi, Kerala 680 653, India. ${ }^{2}$ Department of Soil Science, Kerala Forest Research Institute, Peechi, Kerala 680 653, India.

Received: 14 December 2019 Accepted: 24 March 2020

Published online: 10 June 2020

\section{References}

Adame MF, Santini NS, Tovilla C, Vázquez-Lule A, Castro L, Guevara M (2015) Carbon stocks and soil sequestration rates of tropical riverine wetlands. Biogeosciences 12(12):3805-3818. https://doi.org/10.5194/bg-12-3805-2015

Alongi DM (2012) Carbon sequestration in mangrove forests. Carbon Manag 3(3): 313-322. https://doi.org/10.4155/cmt.12.20

Alongi DM (2014) Carbon cycling and storage in mangrove forests. Annu Rev Mar Sci 6(1):195-219. https://doi.org/10.1146/annurev-marine-010213-135020

Amarasinghe MD, Balasubramaniam S (1992) Net primary productivity of two mangrove forest stands on the northwestern coast of Sri Lanka. Hydrobiologia 247:37-47. https://doi.org/10.1007/BF00008203 
Aryal DR, Ruiz DEM, Marroquín CNT, Ruiz RP, Hernández FG, Venegas JAV et a (2018) Soil organic carbon depletion from forests to grasslands conversion in Mexico: a review. Agriculture 8(11):181. https://doi.org/10.3390/ agriculture8110181

Atwood TB, Connolly RM, Almahasheer H, Carnell PE, Duarte CM, Lewis CJE et al (2017) Global patterns in mangrove soil carbon stocks and losses. Nat Clim Change 7(7):523-528. https://doi.org/10.1038/nclimate3326

Basha CS (1991) Distribution of mangroves in Kerala. Indian For 117:439-449.

Brock PD, Brown LF, Markham, Smith V, Robertson A, Biddick K, Mayhew EM (2006) A field manual for survey methods in tropical marine ecosystems. Frontier-Madagascar Marine Environmental Research Report 17. The Society for Environmental Exploration, London.

Chanan M (2012) Carbon stock estimation stored upground on teak plants vegetation (Tectona grandis Linn. F) in RPH Sengguruh BKPH Sengguruh KPH Malang Public Corporation of Perhutani II East Java. J Gamma 7(2):61-73 [in Indonesian].

Chave J, Coomes D, Jansen S, Lewis SL, Swenson NG, Zanne AE (2009) Towards a worldwide wood economics spectrum. Ecol Lett 12:351-366. https://doi.org/ 10.1111/j.1461-0248.2009.01285.x

de Blécourt M, Brumme R, Xu J, Corre MD, Veldkamp E (2013) Soil carbon stocks decrease following conversion of secondary forests to rubber (Hevea brasiliensis) plantations. PLoS One 8(7):e69357. https://doi.org/10.1371/journal.pone.0069357

Donato DC, Kauffman JB, Murdiyarso D, Kurnianto S, Stidham M, Kanninen M (2011) Mangroves among the most carbon-rich forests in the tropics. Nat Geosci 4(5):293-297. https://doi.org/10.1038/ngeo1123

Duarte CM, Agustí S, Vaqué D, Agawin NSR, Felipe J, Casamayor EO, Gasol JM (2005) Experimental test of bacteria-phytoplankton coupling in the Southern Ocean. Limnol Oceanog 50:1844-1854. https://doi.org/10.4319/lo.2005.50.6.1844

FAO (2007) The world's mangroves 1998-2005. A thematic study prepared in the framework of the Global Forest Resources Assessment 2005, Forestry Paper 153, Rome, p. 77. http://www.fao.org/docrep/010/a1427e/a1427e00.htm.

Fatoyinbo TE, Simard M, Washington-Allen RA, Shugart HH (2008) Landscapescale extent, height, biomass, and carbon estimation of Mozambique's mangrove, forests with Landsat ETM+ and Shuttle Radar Topography Mission elevation data. J Geophys Res Biogeosci 13:G02S06. https://doi.org/10.1029/ 2007JG000551

Forest Survey of India (Ministry of Environment \& Forests) (2009) State of Forest Report. Dehradun, India.

Fujimoto K (2004) Below-ground carbon sequestration of mangrove forests in the Asia-Pacific region. In: Vannucci M (ed.) Mangrove Management and Conservation: Present and Future. United Nations University Press, Tokyo. pp $138-146$

Hogarth PJ (2007) The biology of mangroves and seagrasses (Second edition). Oxford University Press, New York.

Intergovernmental Panel on Climate Change (IPCC). 2006. IPCC Guidelines for National Greenhouse Gas Inventories Volume 4: Agriculture, Forestry and Other Land Use. Institute for Global Environmental Strategies, Hayama Japan. http://www.ipcc-nggip.iges.or.jp/public/2006gl/vol4.html

Jardine SL, Siikamäki JV (2014) A global predictive model of carbon in mangrove soils. Environ Res Lett 9(10):104013. https://doi.org/10.1088/1748-9326/9/10/104013

Kairo JG, Lang'at JKS, Dahdouh-Guebas F, Bosire J, Karachi M (2008) Structural development and productivity of replanted mangrove plantations in Kenya. Forest Ecol Manag 255:2670-2677. https://doi.org/10.1016/j.foreco.2008.01.031

Kamruzzaman Md, Ahmed S, Osawa A (2017) Biomass and net primary productivity of mangrove communities along the Oligohaline zone of Sundarbans, Bangladesh. Forest Ecosyst 4:16. https://doi.org/10.1186/s40663-017-0104-0

Kasawani I, Kamaruzaman J, Nurun-Nadhirah MI (2007) Biological diversity assessment of Tok Bali mangrove forest, Kelantan, Malaysia. WSEAS Trans Environ Dev 3(2):37-44

Kauffman JB, Bhomia RK (2017) Ecosystem carbon stocks of mangroves across broad environmental gradients in West-Central Africa: Global and regional comparisons. PLoS ONE 12(11): e0187749

Kauffman JB, Donato DC (2012) Protocols for the measurement, monitoring and reporting of structure, biomass and carbon stocks in mangrove forests. CIFOR Working Paper No. 86. Center for International Forestry Research (CIFOR), Bogor. https://doi.org/10.17528/cifor/003749

Kauffman JB, Heider C, Cole TG, Dwire KA, Donato DC (2011) Ecosystem carbon stocks of micronesian mangrove forests. Wetlands 31(2):343-352. https://doi. org/10.1007/s13157-011-0148-9

Kauffman JB, Heider C, Norfolk J, Payton F (2014) Carbon stocks of intact mangroves and carbon emissions arising from their conversion in the Dominican Republic. Ecol Appl 24:518-527.
Komiyama A, Ong JE, Poungparn S (2008) Allometry, biomass, and productivity of mangrove forests: a review. Aquatic Botany 89(2):128-137. https://doi.org/10. 1016/j.aquabot.2007.12.006

Komiyama A, Poungparn S, Kato S (2005) Common allometric equations for estimating the tree weight of mangroves. J Trop Ecol 21: 471-477. https:// doi.org/10.1017/S0266467405002476

Kurian CV (1994) Fauna of the mangrove swamps in Cochin estuary. Proceedings of the Asian Symposium on the Mangrove Environment. University of Malaya, Kuala Lumpar, Malaysia, p 226-230.

Kusmana C, Sabiham S, Abe K, Watanabe H (1992) An estimation of above ground tree biomass of a mangrove forest in East Sumatra, Indonesia. Tropics 1(4):243-257. https://doi.org/10.3759/tropics.1.243

Matsui N, Suekuni J, Nogami M, Havanond S, Salikul P (2010) Mangrove rehabilitation dynamics and soil organic carbon changes as a result of full hydraulic restoration and re-grading of a previously intensively managed shrimp pond. Wetlands Ecol Manag 18:233-242. https://doi.org/10.1007/s11273-009-9162-6

Motsara MR, Roy RN (2008) Guide to laboratory establishment for plant nutrient analysis. In: FAO Fertilizer and Plant Nutrition Bulletin, p 19

Murray B, Pendleton L, Jenkins W, Sifleet S (2011) Green payments for blue carbon: economic incentives for protecting threatened coastal habitats. Nicholas Institute for Environmental Policy Solutions, Duke University, Durham, NC

Nellemann C, Corcoran E, Duarte CM, Valdes L, De Young C, Fonseca L, Grimsditch G (2009a) Blue carbon: The role of oceans as carbon sinks. In: Blue carbon: The role of healthy oceans in binding carbon: A rapid response assessment. Nairobi: UNEP; Arendal, Norway: GRID-Arendal

Nellemann C, Corcoran E, Duarte CM, Valdés L, De Young C, Fonseca L, Grimsditch $\mathrm{G}$ (2009b) Blue carbon: a rapid response assessment. Retrieved from. http:// www.grida.no/files/publications/blue-carbon/BlueCarbon_screen.pdf

Niu A, Zhou T, Yang X, Gao Y, Xu S, Lin C (2019) Evaluating litter yield and decomposition for re-vegetated mangroves in a subtropical mudflat. Appl Sci 9(16):3340. https://doi.org/10.3390/app9163340

Padmakumar B, Sreekanth NP, Shanthiprabha V, Paul J, Sreedharan K, Augustine T et al (2018) Tree biomass and carbon density estimation in the tropical dry forest of southern western Ghats, India. IForest 11(4):534-541. https://doi.org/ 10.3832/ifor2190-011

Pandey CN, Pandey R (2013) Carbon sequestration by mangroves of Gujarat, India. Int J Botany Res 3(2):57-70

Ramachandran KK, Balasubramanian G, Kurien J, Thomas J (1985) The mangrove ecosystem of Kerala, its mapping inventory and some environmental aspects. Project report (1984-1985). Thiruvananthapuram: State Committee on Science, Technology and Enviornment. p 51.

SAC (Space Applications Centre) (2012) Coastal Zones of India. Sponsored by Ministry of Environment and Forests, Govt. of India, Space Applications Centre, ISRO, Ahmedabad.

Saha SK, Nair PKR, Nair VD, Kumar BM (2010) Carbon storage in relation to soil size-fractions under tropical tree-based land-use systems. Plant Soil 328:433446. https://doi.org/10.1007/s11104-009-0123-x

Sahu SC, Kumar M, Ravindranath NH (2016) Carbon stocks in natural and planted mangrove forests of Mahanadi Mangrove Wetland, East Coast of India. Curr Sci 110(12):2253-2260. https://doi.org/10.18520/cs/v110/i12/2253-2260

Scharlemann JPW, Tanner EVJ, Hiederer R, Kapos V (2014) Global soil carbon: Understanding and managing the largest terrestrial carbon pool. Carbon Manag 5:81-91. https://doi.org/10.4155/cmt.13.77

Sheikh MA, Kumar M, Bussmann RW (2009) Altitudinal variation in soil organic carbon stock in coniferous subtropical and broadleaf temperate forests in Garhwal Himalaya. Carbon Bal Manag 4:6. https://doi.org/10. 1186/1750-0680-4-6

Sujanapal P, Sasidharan N, \& Kerala State Biodiversity Board (2014) Handbook on mangroves and mangrove associates of Kerala.

Suresh HS, Bhat DM, Ravindranath NH, Sukumar R (2017) Carbon stocks and sequestration potential of Indian Mangroves. Trop Ecol 58(3):547-553

Syamani RA, Agustina, Susilawati, Yusanto N (2012) Carbon stocks above the soil surface at various land cover systems in Amandit Watersheds. J Hutan Tropis 13(2):152-153 (in Indonesian).

Vidyasagaran K, Madhusoodanan VK (2014) Distribution and plant diversity of mangroves in the west coast of Kerala, India. J Biodivers Environ Sci 4(5):38-45

Vinod K, Koya AA, Kunhi Koya VA, Silpa PG, Asokan PK, Zacharia PU, Joshi KK (2018) Biomass and carbon stocks in mangrove stands of Kadalundi Estuarine Wetland, south-west coast of India. Indian J Fisheries 65(2):89-99. https://doi. org/10.21077/ijf.2018.65.2.72473-11 
Walkley A, Black IA (1934) An examination of the degtjareff method for determining soil organic matter, and a proposed modification of the chromic acid titration method. Soil Sci 37:29-38. https://doi.org/10.1097/ 00010694-193401000-00003

\section{Publisher's Note}

Springer Nature remains neutral with regard to jurisdictional claims in published maps and institutional affiliations.

\section{Submit your manuscript to a SpringerOpen ${ }^{\mathcal{O}}$} journal and benefit from:

- Convenient online submission

- Rigorous peer review

- Open access: articles freely available online

- High visibility within the field

- Retaining the copyright to your article

Submit your next manuscript at $\boldsymbol{\wedge}$ springeropen.com 